\title{
Protective effects of fenugreek (Trigonella foenum graecum L.) upon dieldrin-induced toxicity in male rat
}

\author{
Najla Hfaiedh ${ }^{1}$, Hichem Alimi ${ }^{2}$, Jean-Claude Murat ${ }^{3}$ and Abdelfattah Elfeki ${ }^{1}$ \\ ${ }^{1}$ Laboratory of Animal Ecophysiology, Faculty of Sciences, Sfax, Tunisia \\ ${ }^{2}$ Laboratory of Integrated Physiology, Faculty of Sciences, Bizerte, Tunisia \\ ${ }^{3}$ Laboratory of Cellular Biology, Faculty of Medicine, 31073 Toulouse, France
}

\begin{abstract}
The purpose of this study was to evaluate the protective effects of fenugreek (Trigonella foenum graecum L.) upon dieldrin-induced perturbations of haematological parameters and damages to liver and kidney of male Wistar rats. Under our experimental conditions, dieldrin poisoning resulted in 1) an alteration of several haematological parameters, 2) an oxidative stress evidenced by an increase of lipids peroxidation level associated with an increase of superoxide dismutase activity and a decrease of glutathione peroxidase and catalase activities in hepatic and renal tissues, 3 ) increased levels of glucose, total cholesterol, triglycerides, creatinine, urea, uric acid and proteins in blood, 4) increased activities of lactate dehydrogenase, alkaline phosphatase and transaminases in blood. Previous administration of fenugreek was found to hinder these dieldrin-induced damages: all hematological, renal and hepatic biomarkers, level of lipids peroxidation and activities of catalase and glutathione-peroxidase in liver and kidney were kept close to control values. This protective effect is mainly attributed to antioxidant properties of fenugreek.
\end{abstract}

Key words: Dieldrin - Fenugreek (Trigonella foenum graecum L.) - Oxidative stress - LiverKidney

Abbreviations: ALP, alkaline phosphatase; ALT, alanine amino transferase; AST, aspartate amino transferase; CAT, catalase; GPX, glutathione-peroxidase; LDH, lactate dehydrogenase; ROS, reactive oxygen species; SOD, superoxide-dismutase; TBARS, thiobarbituric acid-reactive substances (marker of lipids peroxidation level).

\section{Introduction}

Large-scale application of pesticides to crops and forests may contribute to the increasing presence of toxic substances in the environment. These chemical compounds can find their way to water reservoirs, streams and rivers, thus producing an adverse impact on the aquatic biota, animals and human health (John and Prakash 2003).

Dieldrin is part of a class of synthetic organochlorinated pesticides known as cyclodienes that were commonly used during the 1950-70s. Due to their low volatility, chemical stability, and lipophilic properties, these compounds have

Correspondence to: Najla Hfaiedh, Département de Biologie, Faculté des Sciences, Zarroug, 2100 Gafsa, Tunisia

E-mail: najlaharrathi@yahoo.fr a strong tendency to accumulate in organisms and to persist in the environment (Jorgenson 2001). The Agency for Toxic Substances and Disease Registry (ATSDR) lists dieldrin as the most hazardous cyclodiene pesticide based on its toxicity, widespread distribution, and risk of human exposure (Agency for Toxic Substances and Disease Registry, 2005. CERCLA Priority List of Hazardous Substances. U.S. Dept of Health and Human Services-Public Health Service).

Dieldrin uptake may occur by the oral and dermal routes. The half-life of dieldrin in mice and rats has been estimated to 3 days in previous studies (Hatchar et al. 2007). The most common form of human exposure occurs through the ingestion of contaminated food or water, inhalation of dust or vapor, or absorption through skin. The later being an important factor leading to occupational poisoning by dieldrin. Dieldrin is a central nervous system stimulant: 
after ingestion, toxic doses of dieldrin will cause nausea and vomiting, with signs of neuronal hyperactivity (Kitazawa et al. 2001). Dieldrin has been reported to induce an oxidative stress by interacting with the cell membrane, triggering the generation of reactive oxygen species, what in turn worsens the hepatotoxicity. This can be brought about by a variety of mechanisms, including futile cycling of P-450 enzymes (Parke and Ioannides 1990), mitochondria dysfunction, or a decrease in antioxidants which create a state of oxidative stress in the hepatocytes leading to lipids peroxidation, DNA damage and protein alteration (Stevenson et al. 1999). Interestingly, dieldrin has also been reported to induce glutathione S-transferase activity in mice (Moody et al. 1991), suggesting a possible connection between selective hepatic action of dieldrin and induction of Activator Protein-1. The increase of lipids peroxidation level in the liver of mice fed on dieldrin-containing diet is indicative of membrane alteration.

Dieldrin was found to be immunogenic and to provoke a chemical immunohemolytic anemia (Hayes and Laws 1991). Histopathological studies in rats have shown that exposure to pesticides commonly involves hepatic and renal damages associated with important shifts in serum markers such as creatinine, urea, transaminases and alkaline phosphatase which confirm the involvement of an oxidative stress (Astiz et al. 2009; Hfaiedh et al. 2011; Padma et al. 2011).

In recent years, alternative therapeutic approaches have become very popular (Naravana and Dobrivalm 2000). Nature has been a source of medicinal treatments for thousands of years (King et al. 1998). Fenugreek (Trigonella foenum graecum L.) belongs to the fabaceae family and is cultivated predominantly in Asia, the Mediterranean, and North African regions. It is commonly used as a condiment and seasoning in culinary preparations and it is assumed to possess nutritive and restorative properties (Petit et al. 1993). It has been used in folk medicine for centuries for a wide range of diseases including diabetes mellitus, fever, abdominal colic, boils and carbuncles.

A number of chemicals with medicinal value have been found in fenugreek seed and leaves (Petropoulos 2002). Indeed, fenugreek contains three important chemical constituents with medicinal value, namely, 1) steroidal sapogenins, 2) galactomannans and 3) isoleucine. These constituents have placed fenugreek among the most commonly recognized "nutraceutical" or health food products (Raju et al. 2004). Some medicinal properties attributed to fenugreek are commonly reported: gastro-protective (Pandian et al. 2002), antioxidant (Kaviarasan et al. 2007), antinociceptive (Javan et al. 1997) and antimicrobial (Bhatti et al. 1996). It was used to cure diabetes (Eidi et al. 2007) and hyperthyroidism (Tahiliani and Kar 2003a). Fenugreek steroids have been shown to display a wide range of attractive biological and pharmacologic activities, including apoptosis induction, cell cycle arrest and immunomodulatory and anti-inflammatory actions (Raju et al. 2004). More recently, the efficiency of saponins from fenugreek were established in the alleviation of a wide range of complications pertaining to various diseases, including hypercholesterolemia and obesity (Xie et al. 2010).

4-hydroxyisoleucine, a modified amino acid extracted and purified from fenugreek seeds, was found to display an insulinotropic property in vitro, to stimulate insulin secretion in vivo, and to improve glucose tolerance in rats and dogs (Thakur et al. 1994). Fenugreek was shown to exert a nephroprotective effect by reducing lipids peroxidation level in kidney, to increase sensitivity to insulin and to enhance cellular antioxidant defense in diabetic rats (Eidi et al. 2007). Adding fenugreek seed powder to the diet was found to normalize biomarkers of oxidative damages in alloxandiabetic rats (Ravikumar and Anuradha 1999).

The present study was designed to assess in rats the protective effects of fenugreek (Trigonella foenum graecum L.) upon dieldrin-induced oxidative stress in blood, liver and kidney and the related damages. Examined parameters were haematological parameters, plasma levels of glucose, triglycerides and cholesterol, activities of lactate dehydrogenase (LDH), alkaline phosphatase (ALP), aspartate aminotransferase (AST) and alanine aminotransferase (ALT) in blood serum, urea, creatinine, uric acid and proteins levels in blood serum, and lipids peroxidation level and antioxidant enzymes (SOD, GPX, CAT) activities in liver and kidney.

\section{Materials and Methods}

Rats of Wistar strain were purchased from Siphat Company (Tunis, Tunisia). Prior to experiments, they were kept for 2 weeks in a breeding farm, at $22^{\circ} \mathrm{C}$, with a stable hygrometry, under constant photoperiod. They were given $15 \%$ proteins food pellets (SICO, Sfax, Tunisia) and tap water ad libitum. Dieldrin and other chemicals were obtained from Sigma-Aldrich Company. Dried seeds of fenugreek were obtained from a local Pharmacy and ground to fine powder with a Moulinex grinder. This powder was then mixed with the crushed food pellets $(100 \mathrm{~g} / \mathrm{kg})$.

\section{Experimental design}

3-months-old male rats, about $180 \mathrm{~g}$ body weight, were selected for the experiments which were carried out in the same breeding farm and under the same experimental conditions. The powder obtained from fenugreek dried seeds was mixed with food (100 g per $\mathrm{kg}$ ), so as to administer about $2 \mathrm{~g}$ of fenugreek powder per day and per rat, taking 
into account that each rat ate $20 \mathrm{~g}$ food per day, as evaluated by weighing.

Rats were divided into 4 batches: 1) control group; 2) group of rats treated with dieldrin $(50 \mathrm{mg} / \mathrm{kg}$ bw, as proposed by Bachowski et al. (1998) by forcible feeding for 4 consecutive days; 3 ) group of rats given fenugreek ( $2 \mathrm{~g} / \mathrm{rat} / \mathrm{day})$ for 6 weeks; 4) group of rats treated with fenugreek for 6 weeks, then treated by dieldrin for 4 days $(50 \mathrm{mg} / \mathrm{kg} \mathrm{bw})$. At the end of all treatments, animals from each group were rapidly sacrificed by decapitation in order to minimize the handling stress. Blood was rapidly and immediately collected in plastic tubes, with or without heparin. Serum was obtained by centrifugation of clotted blood $\left(1500 \times g, 15 \mathrm{~min}, 4^{\circ} \mathrm{C}\right)$ and the liver and kidney were removed, cleaned of fat and stored at $-80^{\circ} \mathrm{C}$ until use.

\section{Biochemical assays}

Level of lipids peroxidation was measured as the level of thiobarbituric acid reactive substances (TBARS), according to Yagi (1976). For the assay, $125 \mu$ l of supernatant S1 of liver and kidney were mixed with $175 \mu$ of $20 \%$ trichloroacetic acid containing $1 \%$ butyl-hydroxytoluene and centrifuged $\left(1000 \times g, 10 \mathrm{~min}, 4^{\circ} \mathrm{C}\right)$. Then, $200 \mu \mathrm{l}$ of supernatant S2 was mixed with $40 \mu \mathrm{l}$ of $\mathrm{HCl}(0.6 \mathrm{M})$ and $160 \mu$ of thiobarbituric acid $(0.72 \mathrm{mM})$ and the mixture was heated at $80^{\circ} \mathrm{C}$ for $10 \mathrm{~min}$. The absorbance was measured at $530 \mathrm{~nm}$. The amount of TBARS was calculated using an extinction coefficient of $156 \mathrm{mM}^{-1} \mathrm{~cm}^{-1}$ and expressed in nmoles per mg of protein.

The total ( $\mathrm{Cu}-\mathrm{Zn}$ and $\mathrm{Mn}$ ) superoxide-dismutase (SOD) activity was determined by measuring its ability to inhibit the photoreduction of nitroblue tetrazolium (NBT) (Sun et al. 1988; Durak et al. 1993). One unit of SOD represents the amount inhibiting the photoreduction of NBT by $50 \%$. The activity was expressed as units per mg of protein, at $25^{\circ} \mathrm{C}$.

Glutathione-peroxidase (GPX) activity was assayed according to the method of Flohe and Gunzler (1984).
The activity at $25^{\circ} \mathrm{C}$ was expressed as $\mu$ moles of GSH oxidized/min per $\mathrm{mg}$ of protein.

Catalase (CAT) activity was measured according to Aebi (1984). The reaction mixture $(1 \mathrm{ml})$ contained $100 \mathrm{mM}$ phosphate buffer $(\mathrm{pH}=7), 100 \mathrm{mM} \mathrm{H}_{2} \mathrm{O}_{2}$ and $20 \mu \mathrm{l}$ (about 1-1.5 mg of protein) of liver and kidney homogenate. $\mathrm{H}_{2} \mathrm{O}_{2}$ decomposition was followed at $25^{\circ} \mathrm{C}$ by measuring the decrease in absorbance at $240 \mathrm{~nm}$ for $1 \mathrm{~min}$. Enzyme activity was calculated using an extinction coefficient of $0.043 \mathrm{mM}^{-1} \mathrm{~cm}^{-1}$ and expressed in international units (I.U.), i.e., in $\mu$ moles $\mathrm{H}_{2} \mathrm{O}_{2}$ destroyed $/ \mathrm{min}$ per mg of protein.

Protein content in tissue extracts was determined according to Lowry's method (1951) using bovine serumalbumin as standard.

Red and white blood cells (RBC and WBC), hematocrit (Ht), hemoglobin ( $\mathrm{Hb})$, Mean corpuscular volume (VCM) and blood platelets, from heparinised tubes, were analysed by an electronic automatic apparatus (MAXM, Beckman Coulter Inc., Fullerton, USA).

Levels of glucose, cholesterol, triglycerides and the activities of ALP, LDH, AST, ALT and concentrations of creatinine, urea, uric acid and proteins in serum were determined by kit methods (Spinreact).

\section{Assay of free radical-scavenging activity on $\mathrm{DPPH}$}

The free radical-scavenging activity of fenugreek was evaluated using the stable radical DPPH (2,2-diphenyl-1picrylhydrazyl), according to the method of Grzegorczyk et al. (2007). An aqueous solution of fenugreek (1 ml) at various concentrations $(50-400 \mu \mathrm{g} / \mathrm{ml})$ was added to $1 \mathrm{ml}$ of a $0.1 \mathrm{mM}$ methanolic solution of DPPH and allowed to stand for $30 \mathrm{~min}$ at $27^{\circ} \mathrm{C}$. The absorbance of the sample was measured at $517 \mathrm{~nm}$.

DPPH radical-scavenging activity (RSA), expressed as percent was calculated using the following formula: RSA $\%$ $=\mathrm{A}_{\mathrm{DPPH}}-\left(\mathrm{A}_{\text {sample }}-\mathrm{A}_{\text {control }}\right) \times 100 / \mathrm{A}_{\mathrm{DPPH}}$.

Table 1. Hematological parameters in control, dieldrin-treated, fenugreek given and fenugreek- and dieldrin-treated rats

\begin{tabular}{lrcrc}
\hline \multirow{2}{*}{ Parameter } & \multicolumn{4}{c}{ Group } \\
\cline { 2 - 5 } & \multicolumn{1}{c}{$\mathrm{C}$} & $\mathrm{D}$ & $\mathrm{Fe}$ & $\mathrm{DFe}$ \\
\hline $\mathrm{RBC}\left(10^{6} \mu \mathrm{l}\right)$ & $8.07 \pm 0.46$ & $6.68 \pm 0.6^{* *}$ & $7.93 \pm 0.28^{++}$ & $8.48 \pm 0.75^{++}$ \\
$\mathrm{WBC}\left(10^{3} / \mu \mathrm{l}\right)$ & $22.27 \pm 2.06$ & $11.7 \pm 0.53^{* *}$ & $25.4 \pm 2.52^{++}$ & $19.15 \pm 1.14^{++}$ \\
$\mathrm{Hb}(\mathrm{g} / \mathrm{dl})$ & $14.12 \pm 0.83$ & $11.22 \pm 0.51^{* *}$ & $13.75 \pm 0.43^{++}$ & $14.45 \pm 0.42^{++}$ \\
$\mathrm{VCM}\left(10^{-6} \mu \mathrm{m}^{3} / \mathrm{RBC}\right)$ & $49.62 \pm 1.76$ & $22.4 \pm 0.62^{* *}$ & $48.02 \pm 0.8^{++}$ & $48.12 \pm 0.85^{++}$ \\
$\mathrm{PLT}\left(10^{3} / \mu \mathrm{l}\right)$ & $845.25 \pm 41.2$ & $1163.25 \pm 46.44^{* *}$ & $881.5 \pm 78.2^{++}$ & $983 \pm 73.7^{++}$ \\
$\mathrm{Ht}(\%)$ & $38.9 \pm 1.9$ & $32.9 \pm 1.22^{* *}$ & $37.5 \pm 1.14^{++}$ & $40.8 \pm 2.9^{++}$ \\
\hline
\end{tabular}

Values are the mean $\pm \mathrm{SD}(n=6) .{ }^{* *} p \leq 0.01$ significant difference as compared to $\mathrm{C}$ group; ${ }^{++}$significant difference when comparing $\mathrm{D}$ and $\mathrm{Fe}$ and $\mathrm{DFe}$ groups. C, control group; D, dieldrin-treated rats; Fe, fenugreek given rats; DFe, fenugreek- and dieldrin-treated rats; RBC, erythrocytes; WBC, leucocytes; Hb, hemoglobin; VCM, mean corpuscular volume; PLT, blood platelets; Ht, hematocrit. 


\section{Statistical analysis}

Two independent experiments, each carried out on 24 rats, were performed. Data were expressed as mean \pm standard deviation (SD). Statistical significance was assessed by Student's test, $p<0.05$ being considered statistically significant.

\section{Results}

\section{Haematological parameters}

As shown in Table 1, dieldrin treatment caused a significant reduction of red blood cells $(-17 \%)$, white blood cells $(-48 \%), \mathrm{Hb}(-21 \%), \mathrm{Ht}(-15 \%), \mathrm{VCM}(-54 \%)$ values and a significant increase in platelets number $(+38 \%)$, as compared to controls. Previous administration of fenugreek reduced the dieldrin-induced alteration of these parameters (DFe group).

\section{Blood glucose, cholesterol and triglycerides levels}

As seen in Table 2, dieldrin treatment induced a significant increase of glucose, cholesterol and triglycerides by $+74 \%$, $+65 \%,+50 \%$, respectively, as compared to controls. Previous supplementation with fenugreek maintained these parameters to almost control values.

\section{Serum markers of damages to liver and kidney}

LDH, ALP, AST and ALT are released into the blood when certain organs or tissues are injured. As shown in Table 2, activities of these enzymes were significantly higher in dieldrin-treated rats than in controls by $+53 \%,+41 \%,+28 \%$, $+60 \%$, respectively.
Dieldrin treatment also induced severe kidney damages evidenced by a significant increase of creatinine, urea and uric acid and proteins in serum (Fig. 1). When dieldrintreated rats were previously treated with fenugreek, all these biomarkers were maintained to almost normal values.

\section{Oxidative damages}

TBARS levels, which reflect the lipids peroxidation level, were increased in hepatic and renal tissues of dieldrin-treated rats, as compared to controls, by $+113 \%$ and $+106 \%$, respectively (Fig. 3 and 4). Previous administration of fenugreek reduced this increase of TBARS levels.

\section{Antioxidant activities}

Activities of enzymes which protect against oxidative stresses, i.e., CAT and GPX were found to be respectively reduced by $-47 \%$ and $-56 \%$ in liver and by $-49 \%$ and $-39 \%$ in kidney of dieldrin-treated rats, whereas SOD activity was increased in kidney and liver by $167 \%$ and $53 \%$, respectively (Fig. 3 and 4). These changes, revealing a failing defence against the oxidative stress, were largely corrected in animals previously given fenugreek.

\section{Discussion}

In recent years, there was considerable interest in free radicals-mediated damages in biological systems, especially when related to an exposure to pesticides scattered in the environment (Banerjee et al. 2001). Under our experimental conditions, exposure of rats to dieldrin altered hematological parameters and increased platelets number in blood, as compared to controls rats. Our results are in line with previous reports which demonstrate that pesticides exposure altered

Table 2. Blood glucose, cholesterol, triglycerides levels and activities of lactate dehydrogenase, aspartate aminotransferase, alanine aminotransferase and alkaline phosphatase in control, dieldrin-treated, fenugreek given and fenugreek- and dieldrin-treated rats

\begin{tabular}{lcccc}
\hline \multirow{2}{*}{ Parameter } & \multicolumn{3}{c}{ Group } \\
\cline { 2 - 5 } & $\mathrm{C}$ & $\mathrm{D}$ & $\mathrm{Fe}$ & $\mathrm{DFe}$ \\
\hline Glucose (mmol/l) & $6.567 \pm 0.5$ & $11.6 \pm 0.48^{* *}$ & $6.37 \pm 0.46^{++}$ & $8.35 \pm 0.4^{++}$ \\
Cholesterol (mmol/l) & $1.62 \pm 0.06$ & $2.78 \pm 0.032^{* *}$ & $1.35 \pm 0.1^{++}$ & $1.4 \pm 0.1^{++}$ \\
Triglycerides (mmol/l) & $0.86 \pm 0.1$ & $1.29 \pm 0.08^{* *}$ & $0.73 \pm 0.09^{++}$ & $0.87 \pm 0.03^{++}$ \\
LDH (IU/l) & $1200 \pm 58.7$ & $1834 \pm 169^{* *}$ & $1272 \pm 93.09^{++}$ & $1385.7 \pm 49^{++}$ \\
ALT (IU/l) & $76.25 \pm 6.4$ & $97.5 \pm 1.3^{* *}$ & $84 \pm 7.25^{++}$ & $97.5 \pm 5.7$ \\
AST (IU/l) & $244.8 \pm 15.32$ & $390 \pm 29^{* *}$ & $234.5 \pm 18.2^{++}$ & $283.2 \pm 18.23^{++}$ \\
ALP (IU/l) & $438 \pm 33.9$ & $616 \pm 46.5^{* *}$ & $430.5 \pm 60.6^{++}$ & $412 \pm 14.24^{++}$ \\
\hline
\end{tabular}

Values are the mean $\pm \mathrm{SD}(n=6) .{ }^{* *} p \leq 0.01$ significant difference as compared to C group; ${ }^{++}$significant difference when comparing $\mathrm{D}$ and Fe and DFe groups. LDH, lactate dehydrogenase; ALT, alanine amino transferase, AST, aspartate amino transferase; ALP, alkaline phosphatase. Other abbreviations see Table 1. 
A

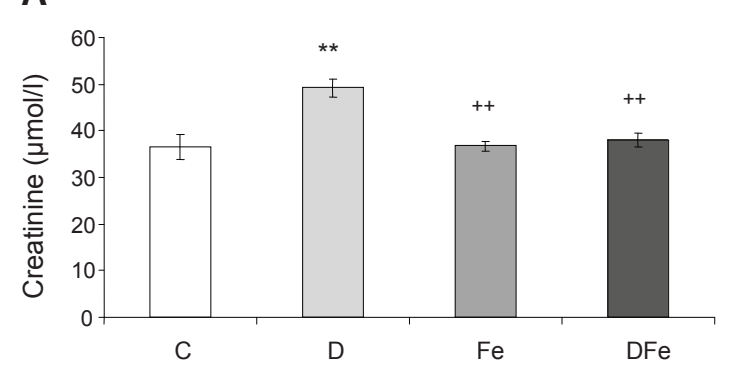

C

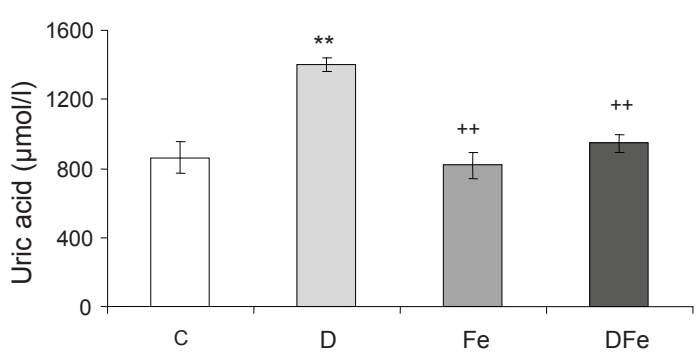

B

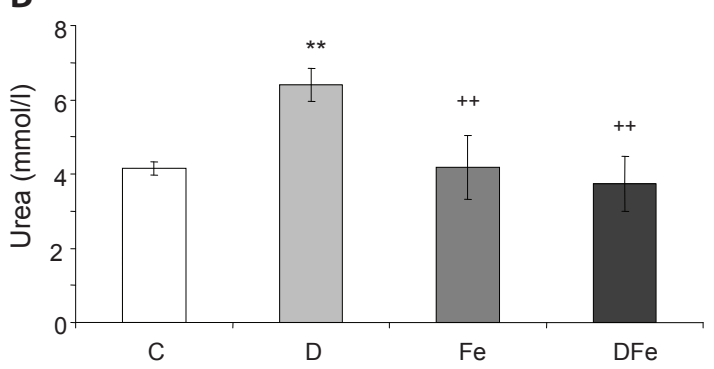

D

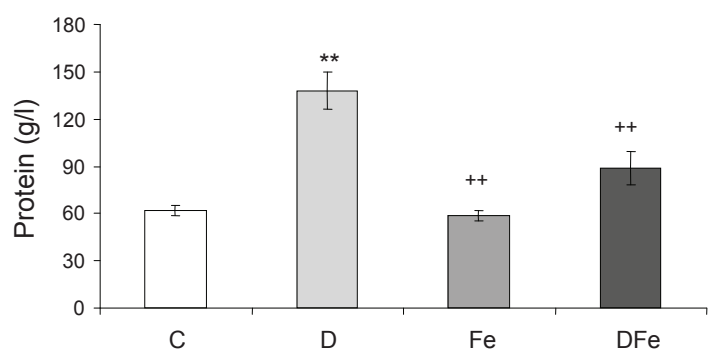

Figure 1. Serum creatinine (A), urea (B), uric acid (C) and proteins (D) levels in: control, dieldrin-treated, fenugreek-treated and fenugreek- and dieldrin-treated rats. Values are the mean $\pm \mathrm{SD}(n=6)$; ${ }^{* *}$ significant difference as compared to $\mathrm{C}$ group $(p \leq 0.01)$. ${ }^{++}$significant difference when comparing D and Fe or DFe groups. C, control rats, D, dieldrin-treated rats, Fe, fenugreek given rats; DFe, rats previously given fenugreek then treated by dieldrin.

hematological parameters in rats (Fetoui et al. 2008). An anemia associated with the accumulation of this pesticide in blood was also reported by Hayes and Laws (1991).

In the current study, the significant reduction in erythrocytes count and hemoglobin value might be due to the inhibition of erythropoiesis and hemosynthesis, and to an increase in the rate of erythrocytes destruction by over-production of oxidative radicals leading to erythrocytes membrane lipids peroxidation (Kato et al. 2006). Liver, being a major site of xenobiotics metabolism, can be altered by dieldrin accumulation. Alteration of iron reduction in hepatic parenchyma could, in turn, alter haemoglobin synthesis and hematological parameters. In our study, damage to liver is also evidenced by the hyperglycaemia, the increased levels of cholesterol and triglycerides and the significant increase of ALP, AST, ALT and LDH activities in blood. This confirms data of Bachowski et al. (1998) and is consistent with histopathological observations of acute hepatitis after ingestion of dieldrin (Kolaja et al. 1996). Adverse effect of dieldrin on liver may result from the following scheme: dieldrin is absorbed from the gastrointestinal tract via the hepatic portal vein (Hayes and Laws 1991), easily penetrates cell membranes due to its lipophilicity, inhibits $\mathrm{Mg}^{2+}$-ATPase and stimulates 5'-nucleotidase and NADHdehydrogenase activities in hepatocyte (Stevenson et al. 1995) and there is metabolized by the microsomal cytochrome P-450 system into mainly hydrophilic metabolites which cause liver injury (Hayes and Laws 1991).
The fact that antioxidants attenuate the adverse effects of dieldrin supports the idea that an oxidative stress contributes to its neurotoxicity and hepatotoxicity (Kitazawa et al. 2001, 2003). Dieldrin poisoning significantly increases carbonyl level and decreases total glutathione level in the striatum what may, in part, explain its neurotoxicity (Hatcher et al. 2007). Dieldrin also induces an oxidative stress in kidney, what explains the increase of creatinine and urea levels in blood (Donadio et al. 1997). Increase of blood urea level is known to be correlated with an increased catabolism of proteins and/or an active conversion of ammonia into urea resulting from a high activity of arginase. Our results

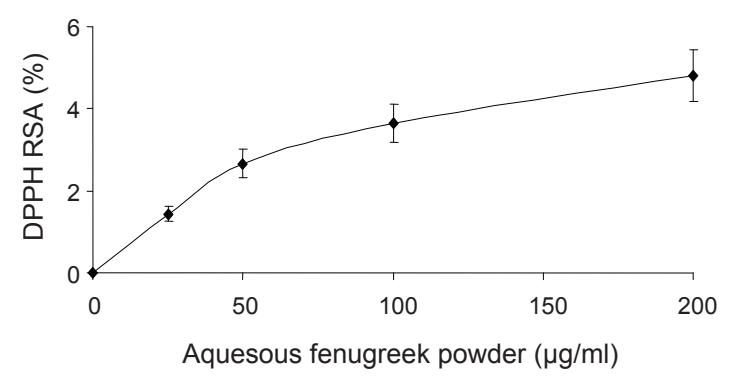

Figure 2. Scavenging activity of an aqueous Fenugreek powder (at final concentration ranging from 0 to $200 \mu \mathrm{g} / \mathrm{ml}$ ) upon the DPPH (2,2-diphenyl-1-picrylhydrazyl) radical. Each value is the mean of 3 separate assays \pm SD. RSA, radical scavenging activity. 
corroborate findings of Padma et al. (2011) who suggested that organochlorinated pesticides such as lindane induced hepatic and renal toxicity in rat. Oxidative stress, changes in biochemical parameters and enzyme activities in the kidney of male rat was investigated after exposure to lambda-cyhalothrin by Fetoui et al. (2010). These authors reported that all adverse effects were alleviated when rats were previously treated with a fenugreek extract.

Kaviarasan et al. (2004) reported that polyphenols present in fenugreek seeds prevented in vitro the oxidative hemolysis and lipids peroxidation induced by $\mathrm{H}_{2} \mathrm{O}_{2}$ in human erythrocytes. This could explain the reduction of dieldrin-induced anemia we observed in rats previously given fenugreek in the diet.
Raju et al. (2004) and Bin-Hafeez et al. (2003) published works showing that fenugreek restored glucose homeostasis by affecting glycolytic, gluconeogenic, and lipogenic enzymes and by protecting $\beta$-cells from oxidative damage. In addition, several studies have shown the presence of steroid saponins in fenugreek seeds (Petit et al. 1993; Yoshikawa et al. 1997) which inhibit intestinal glucose uptake in vitro (Alhabori et al. 2001). These observations support our finding concerning the correction of dieldrin-induced hyperglycemia when fenugreek was added in the diet.

All other biomarkers of hepatic and renal damages due to dieldrin (TG, Ch, LDH, AST, ALT, ALP, creatinine, urea, uric acid and proteins) are maintained to almost normal values in
A
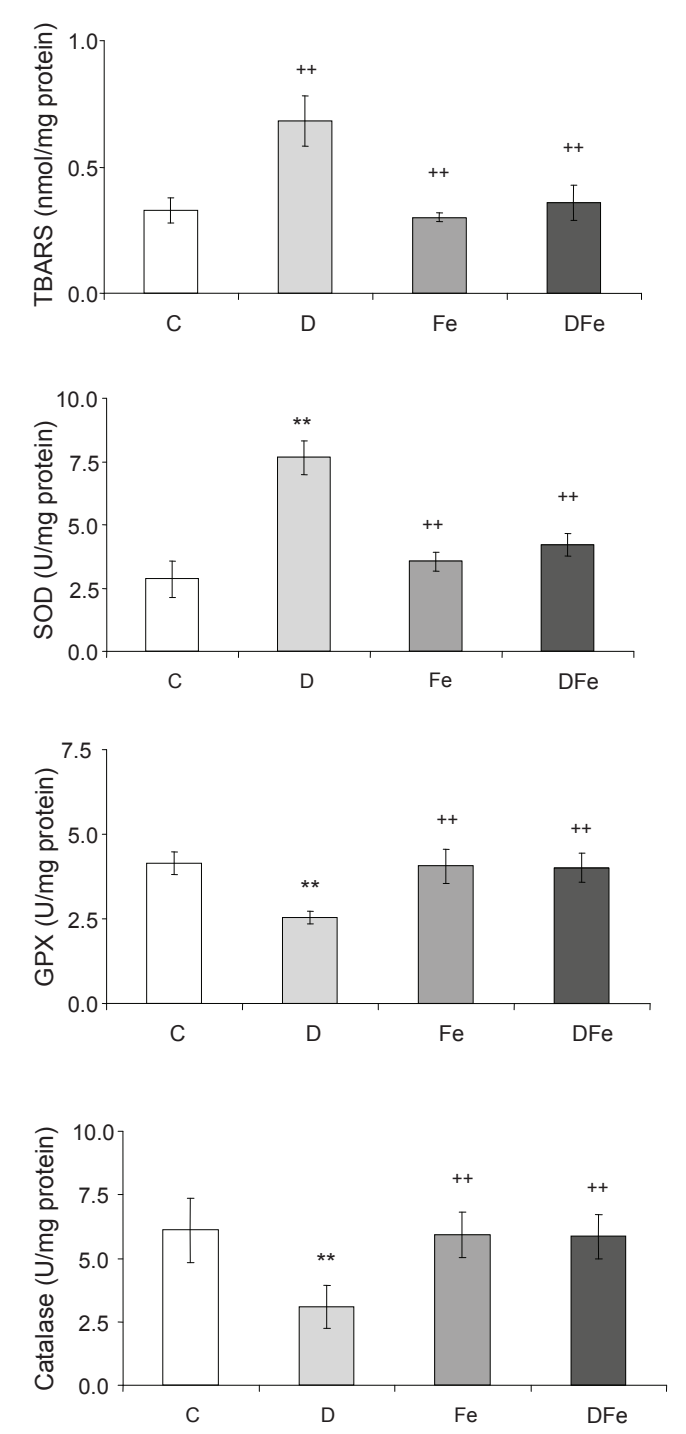

B
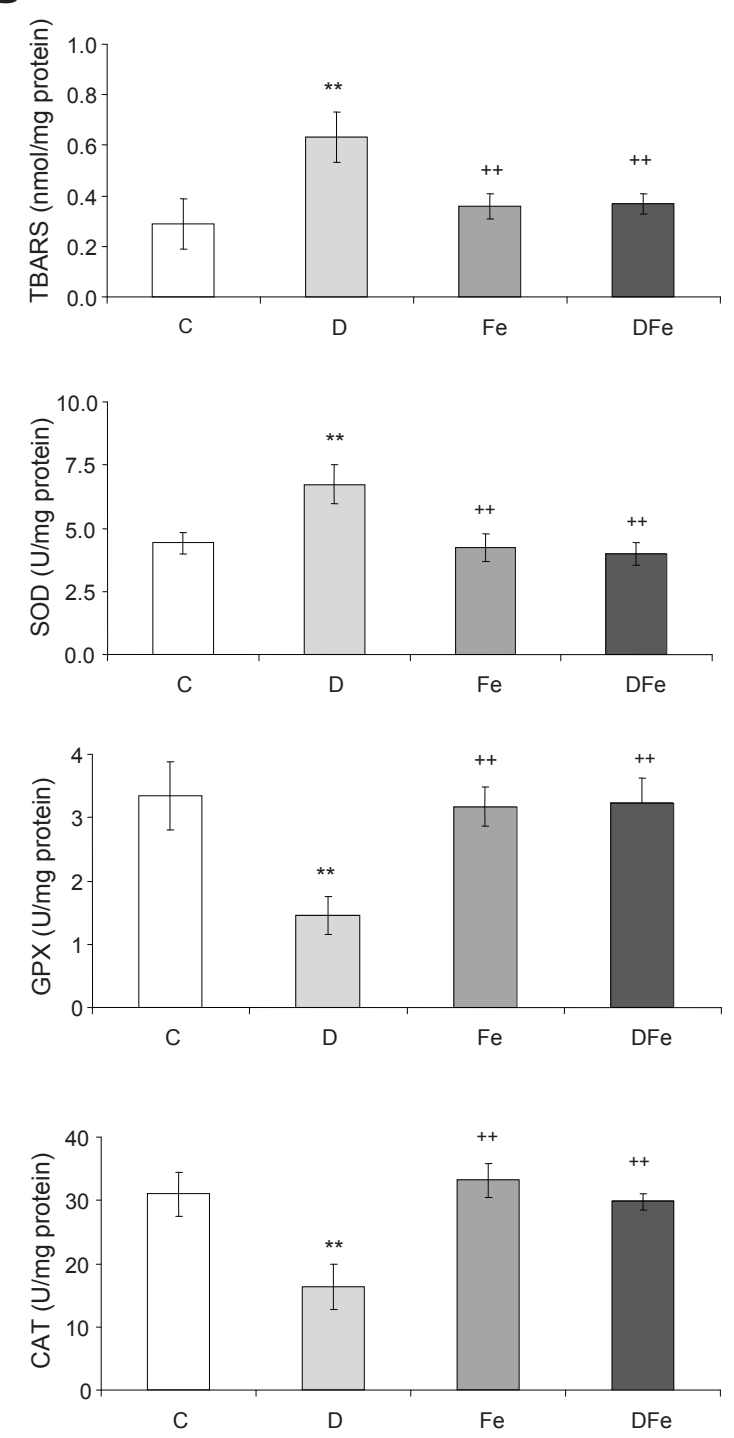

Figure 3. TBARS levels and activities of SOD, GPX and CAT in kidney (A) and liver (B) after 6 weeks and 4 days of treatment in: control, dieldrin-treated, fenugreek given and rats previously given fenugreek then treated by dieldrin. Values are the mean $\pm \operatorname{SD}(n=6)$. ${ }^{* *}$ significant difference as compared to C group $(p \leq 0.01) ;{ }^{++}$significant difference when comparing D, Fe and DFe groups. 
our animals previously fed on the fenugreek containing diet. In accordance with these findings, fenugreek extract was reported to decrease the cholesterol, triglycerides, uric acid, urea and creatinine levels and to reduce transaminases activities in blood of diabetic rats (Eidi et al. 2007). It is well known that immunological disorders and hyperglycemia are the most important indices of chronic diseases resulting from a long-lasting oxidative stress (Gumieniczek et al. 2006). In our study, fenugreek reduced lipids peroxidation level and boosted the antioxidant systems in liver and kidney. It confirms previous works showing that fenugreek seed powder added in the diet reduced biomarkers of oxidative damages in alloxan-diabetic rats (Ravikumar and Anuradha 1999). Kaviarasan et al. (2007) also reported that an extract of fenugreek seeds contained antioxidants and protected cellular structures from oxidative damages.

Paying attention to the effects of fenugreek alone (group $\mathrm{Fe}$ ), we conclude that fenugreek by itself produces no deleterious effects. For instance, fenugreek reduced the dieldrininduced hyperglycemia but did not reduce the blood glucose level when administered alone, as compared to controls.

In our study, fenugreek prevented the alterations of antioxidative defense parameters induced by dieldrin in blood, liver and kidney. This protective effect of fenugreek can be attributed to scavenging free radicals properties as shown by the DPPH test in vitro (Fig. 2).

Acknowledgement. The present work was supported by the Laboratory of Physiology, Faculty of Sciences at Sfax and the Department of Biology, Faculty of Sciences at Gafsa, Tunisia.

\section{References}

Aebi H. (1984): Catalase in vitro. Methods Enzymol. 105, 121-126 http://dx.doi.org/10.1016/S0076-6879(84)05016-3

Al-Habori M., Raman A., Lawrence M. J., Skett P. (2001): In vitro effect of fenugreek extracts on intestinal sodium-dependent glucose uptake and hepatic glycogen phosphorylase A. Int. J. Exp. Diabetes Res. 2, 91-99 http://dx.doi.org/10.1155/EDR.2001.91

Astiz M., DeAlaniz J. T., Marra C. A. (2009): Effect of pesticides on cell survival in liver and brain rat tissues. Ecotoxicol. Environ. Saf. 72, 2025-2032 http://dx.doi.org/10.1016/j.ecoenv.2009.05.001

Bachowski S., Xu Y., Stevenson D. E., Walborg Jr. E. F., Klauning J. E. (1998): Role of oxidative stress in the selective toxicity of dieldrin in the mouse liver. Toxicol. Appl. Pharmacol. 150, 301-309 http://dx.doi.org/10.1006/taap.1998.8372

Banerjee B. D., Seth V., Ahmed R. S. (2001): Pesticides-induced oxidative stress: perspectiveness and trends. Rev. Environ. Health 16, 1-40 http://dx.doi.org/10.1515/REVEH.2001.16.1.1

Bhatti M. A., Khan M. T. J., Ahmed B., Jamshaid M., Ammad W. (1996): Antibacterial activity of Trigonella foenum-graecum seeds. Fitoterapia $67,372-374$
Bin-Hafeez B., Haque R., Parvez S., Pandey S., Sayeed I., Raisuddin S. (2003): Immunomodulatory effects of fenugreek (Trigonella foenum graecum L) extract in mice. Int. Immunopharmacol. 3, 257-265 http://dx.doi.org/10.1016/S1567-5769(02)00292-8

Donadio C., Lucchesi A., Tramonti G., Bianchi C. (1997): Creatinine clearance predicted from body cells mass is a good indicator of renal function. Kidney Int. 52, 166-168

Durak I., Yurtarslanl Z., Canbolat O., Akyol O. (1993): A methodological approach to superoxide dismutase (SOD) activity assay based on inhibition of nitroblue tetazolium (NBT) reduction. Clin. Chim. Acta 214, 103-104 http://dx.doi.org/10.1016/0009-8981(93)90307-P

Eidi A., Eidi M., Sokhteh M. (2007): Effect of fenugreek (Trigonella foenum-graecum L) seeds on serum parameters in normal and streptozotocin-induced diabetic rats. Nutr. Research 27, 728-733 http://dx.doi.org/10.1016/j.nutres.2007.09.006

Fetoui H., Garoui M., Makni-ayadi F., Zeghal N. (2008): Oxidative stress induced by lambda-cyhalothrin (LTC) in rat erythrocytes and brain: Attenuation by vitamin C. Environ. Toxicol. Pharmacol. 26, 225-231 http://dx.doi.org/10.1016/j.etap.2008.04.002

Fetoui H., Makni M., Garoui M., Zeghal N. (2010): Toxic effects of lambda-cyhalothrin, a synthetic pyrethroid pesticide, on the rat kidney: Involvement of oxidative stress and protective role of ascorbic acid. Exp. Toxicol. Pathol. 62, 593-599 http://dx.doi.org/10.1016/j.etp.2009.08.004

Flohé L., Günzler W. A. (1984): Assays of glutathione peroxidase. Methods Enzymol. 105, 114-121 http://dx.doi.org/10.1016/S0076-6879(84)05015-1

Grzegorczyk I., Matkowski A., Wysokinska H. (2007): Antioxidant activity of extracts from in vitro cultures of Salvia officinalis L. Food Chem. 104, 536-541 http://dx.doi.org/10.1016/j.foodchem.2006.12.003

Gumieniczek A., Hopkala H., Rolinski J., Bojarska-Junak A. (2006): Interleukin- 6 and oxidative stress in plasma of alloxan-induced diabetic rabbits after pioglitazone treatment. Immunopharmacol. Immunotoxicol. 28, 81-91 http://dx.doi.org/10.1080/08923970600625785

Hayes W. J., Jr., Laws E. R., Jr. (1991): Handbook of Pesticide Toxicology. pp. 743-780, Academic Press, San Diego

Hatcher J. M., Richardson J. R., Guillot T. S., McCormack A. L., Di Monte D. A., Jones D. P., Pennell K. D., Miller G. W. (2007): Dieldrin exposure induces oxidative damage in the mouse nigrostrial dopamine system. Exp. Neurol. 204, 619-630 http://dx.doi.org/10.1016/j.expneurol.2006.12.020

Hfaiedh N., Murat J. C., Elfeki A. (2011): Protective effects of garlic (Allium sativum) extract upon lindane-induced oxidative stress and related damages in testes and brain of male rats. Pesticide Biochem. Physiol. 100, 187-192 http://dx.doi.org/10.1016/j.pestbp.2011.03.009

Javan M., Ahmadiani A., Semnanian S. Kamalinejad M. (1997): Antinociceptive effects of Trigonella foenum-graecum leaves extract. J. Ethnopharmacol. 58, 125-129 http://dx.doi.org/10.1016/S0378-8741(97)00089-5

John P. J., Prakash A. (2003): Bioaccumulation of pesticides on some organs of freshwater catfish Mystus vittatus. Bull. Environ. Contam. Toxicol. 70, 1013-1016 
http://dx.doi.org/10.1007/s00128-003-0083-4

Jorgenson J. L. (2001): Aldrin and dieldrin: a review of research on their production, environmental deposition and fate, bioaccumulation, toxicology, and epidemiology in the United States. Environ. Health Perspect. 109, 113-139 http://dx.doi.org/10.2307/3434852

Kato G. J., McGowan V., Machado R. F., Little J. A., Taylor J., Morris C. R., James S., Wang N. X., Poljakovic M., Morris S. M., Gladwin M.T. (2006): Lactate dehydrogenase as a biomarker of hemolysis-associated nitric oxide resistance, priapism, leg ulceration, pulmonary hypertension, and death in patients with sickle cell disease. Blood 107, 2279-2285

http://dx.doi.org/10.1182/blood-2005-06-2373

Kaviarasan S., Vijayalakshmi C. V., Anuradha K. (2004): Polyphenol-rich extract of fenugreek seeds protect erythrocytes from oxidative damage. Plant Foods Hum. Nutr. 59, 143-147 http://dx.doi.org/10.1007/s11130-004-0025-2

Kaviarasan S., Naik G. H., Gangabhagirathi R., Anuradha C. V., Priyadarsini K. I. (2007): In vitro studies on antiradical and antioxidant activities of fenugreek (Trigonella foenum graecum) seeds. Food Chemistry 103, 31-37 http://dx.doi.org/10.1016/j.foodchem.2006.05.064

King H., Aubert R. E., Herman W. H. (1998): Global burden of diabetes, 1995-2025: Prevalence, numerical estimates, and projections. Diabetes Care 21, 1414-1431 http://dx.doi.org/10.2337/diacare.21.9.1414

Kitazawa M., Anantharam V., Kanthasamy A. G. (2001): Dieldrininduced oxidative stress and neurochemical changes contribute to apoptopic cell death in dopaminergic cells. Free Radic. Biol. Med. 31, 1473-1485 http://dx.doi.org/10.1016/S0891-5849(01)00726-2

Kitazawa M., Anantharam V., Kanthasamy A. G. (2003): Dieldrin induces apoptosis by promoting caspase-3-dependent proteolytic cleavage of protein kinase Cdelta in dopaminergic cells; relevance to oxidative stress and dopaminergic degeneration. Neuroscience 119, 945-964 http://dx.doi.org/10.1016/S0306-4522(03)00226-4

Kolaja K. L., Stevenson D. E., Johnson J. T., Walborg E. F., Jr., Klauning J. E. (1996): Subchronic effects of dieldrin and Phenobarbital on hepatic DNA synthesis in mice and rats. Fundam. Appl. Toxicol. 29, 219-228 http://dx.doi.org/10.1093/toxsci/29.2.219

Lowry O. H., Rosebrough N. J., Farr A. L., Randall R. J. (1951): Protein measurement with the Folin phenol reagent. J. Biol. Chem. 193, 265-275

Moody D. E., Montigomery K. A., Ashour M. B., Hammoch B. D. (1991): Effects of environmentally encountered epoxides on mouse liver epoxidemetabolizing enzymes. Biochem. Pharmacol. 41, 1625-1637 http://dx.doi.org/10.1016/0006-2952(91)90163-Y

Narayana D. B., Dobriyalm R. M. (2000): Complimentary medecines and 21st century therapeutics: challenges for pharmacologist. In: Pharmacology and Therapeutics in the New Millennium. (Ed. S. K. Gupta), pp. 326-335, New Delhi (India), Narosa Publishing House

Padma V. V., Sowmya P., Felix T. A., Baskaran R., Poornima P. (2011): Protective effect of gallic acid against lindane induced toxicity in experimental rats. Food Chem. Toxicol. 49, 991-998 http://dx.doi.org/10.1016/j.fct.2011.01.005

Pandian R. S., Anuradha C. V., Viswanathan P. (2002): Gastroprotective effect of fenugreek seeds (Trigonella foenum-graecum) on experimental gastric ulcers in rats. J. Ethnopharmacol. 81, 393-397 http://dx.doi.org/10.1016/S0378-8741(02)00117-4

Parke D. V., Ioannides C. (1990): Role of cytochrome P-450. In: Mouse Liver Tumor Production. Mouse Liver Carcinogenesis: Mechanisms and Species Comparisons. (Eds. D. E. Stevenson, J. M. Ward and H. C. Pitot), pp. 215-230, Alan R. Liss, New York

Petit P. R., Sauvaire Y. D., Hillaire-Buys D. M., Lectone O. M., Baissac Y. G., Ponsin G. R., Ribes G. R. (1995): Steroids saponins from fenugreek seeds: extraction, purification, and pharmacological investigation on feeding behavior and plasma cholesterol. Steroids 60, 674-680 http://dx.doi.org/10.1016/0039-128X(95)00090-D

Petropoulos G. A. (2002): Fenugreek. The genus Trigonella. In: Medicinal and Aromatic Plants - Industrial Profiles. pp. 1-127, Taylor and Francis, London and New York

Raju J., Patlotta J. M. R., Swamy M. V., Rao C. V. (2004): Diosgenin, a steroid saponin of Trigonella foenum graecum (Fenugreek), inhibits azoxymethane-induced aberrant crypt foci formation in F344 rats and induces apoptosis in HT-29 human colon cancer cells. Cancer Epidemiol. Biomarkers Prev. 13, 1392-1398

Ravikumar P., Anuradha C. V. (1999): Effect of fenugreek seeds on blood lipid peroxidation and antioxidants in diabetic rats. Phytother. Res. 13, 197-201 http://dx.doi.org/10.1002/(SICI)1099-1573(199905)13:3<197:: AID-PTR413>3.0.CO;2-L

Stevenson D. E., Kehrer J. P., Kolaja K. L., Walborg E. F., Klauning J. E. (1995): Effect of dietary antioxidants on dieldrin-induced hepatotoxicity in mice. Toxicol. Lett. 75, 177-183 http://dx.doi.org/10.1016/0378-4274(94)03178-A

Sun Y., Oberley L. W., Li Y. (1988): A simple method for clinical assay of superoxide Dismutase. Clin. Chem. 34, 497-500

Tahiliani P., Kar A. (2003): The combined effects of Trigonella and Allium extracts in the regulation of hyperthyroidism in rats. Phytomedicine 10, 665-668 http://dx.doi.org/10.1078/0944-7113-00277

Thakur A. M., Sarvaiya J. G., Bhavsar S. K. (1994): Studies on anti-inflammatory activities of trigonella in rats. In: Update Ayurveda, Bombay, India

Xi M., Hai C., Tang H., Wen A., Chen H., Liu R., Liang X., Chen M. (2010): Antioxidant and antiglycation properties of triterpenoid saponins from Aralia taibaiensis traditionally used for treating diabetes mellitus. Redox Rep. 15, 20-28 http://dx.doi.org/10.1179/174329210X12650506623041

Yagi K. (1976): A simple fluorometric assay for lipoperoxide in blood plasma. Biochem. Med. 15, 212-216 http://dx.doi.org/10.1016/0006-2944(76)90049-1

Yoshikawa M., Murakami T., Komatsu H., Murakami N., Yamahara J., Matsuda H. (1997): Medicinal foodstuffs. IV. Fenugreek seed. (1): structures of trigoneosides Ia, Ib, IIb, IIIa, and IIIb, new furostanol saponins from the seeds of Indian Trigonella foenum graecum L. Chem. Pharm. Bull. 45, 81-87 http://dx.doi.org/10.1248/cpb.45.81

Received: February 22, 2012

Final version accepted: April 26, 2012 